\title{
PELAYANAN ADMINISTRASI PERTANAHAN DI KECAMATAN JEKAN RAYA KOTA PALANGKA RAYA
}

\author{
Land Administration Services in Jekan Raya District, Palangka Raya City
}

\section{Irwani* \\ Desi Andayani}

Universitas Muhammadiyah Palangkaraya, Palangka Raya, Central Kalimantan, Indonesia email: irwani@umpalangkaraya.ac.id

\section{Kata Kunci:}

Administrasi Pertanahan

Kecamatan Jekan Raya

Pelayanan Publik

\section{Keywords:}

Land Administration

Jekan Raya Regency

Public Service

\section{Accepted}

August 2018

Published

October 2018

\begin{abstract}
Abstrak
Penelitian ini bertujuan untuk mengkaji dan menjelaskan bagaimana pelaksanaan tertib administrasi pertanahan di Kecamatan Jekan Raya Kota Palangka Raya. Metode penelitian yang digunakan adalah deskriptif kualitatif karena masalah yang dibawa oleh peneliti masih belum jelas bersifat sementara dan bersifat holistic (menyeluruh) sumber data dalam penelitian ini terdiri dari data primer dan data sekunder, yang menjadi data primer adalah Kepala bagian Seksi Pemerintahan Registrasi Pertanahan, Petugas pelayanan pertanahan dan masyarakat yang melakukan pelayanan pertanahan di Kecamatan Jekan Raya Kota Palangka Raya. Teknik pengumpulan data dalam penelitian ini yaitu observasi, wawancara dan dokumentasi. Berdasarkan hasil penelitian bahwa pelayanan administrasi pada pertanahan diketahui masih belum maksimal karena petugas pelayanan masih seringkali tidak tepat waktu dalam memberikan pelayanan, masih kurangnya kehandalan petugas dalam memberikan pelayanan, masih kurangnya sarana fasilitas penunjang pelayanan, daya tanggap petugas dalam proses pelayanan masih terbatas, serta jaminan dalam proses pelayanan dalam proses pelayanan masih adanya petugas memberikan pelayanan dengan wajah judes.
\end{abstract}

\begin{abstract}
This study aims to examine and explain how the orderly implementation of land administration in the District of Jekan Raya, Palangka Raya City. The research method used is descriptive qualitative because the problems brought by researchers are still unclear in nature and are holistic (overall) sources of data in this study consisting of primary data and secondary data, which is the primary data is the Head of Government Section Land Registration, Officer land services and communities that conduct land services in Jekan Raya Subdistrict, Palangka Raya City. Data collection techniques in this study are observation, interview and documentation. Based on the results of the study that the administrative service in the land is known to be still not optimal because service personnel are still often not on time in providing services, still lack of reliability of officers in providing services, still lack of facilities to support services, staff responsiveness in the service process is still limited in the service process in the service process there are still officers providing services with bitchy faces.
\end{abstract}

\section{PENDAHULUAN}

Pelayanan pemerintah adalah suatu kegiatan yang merupakan perwujudan dari salah satu fungsi pemerintah itu sendiri, yang bertujuan untuk mensejahterakan masyarakat. Berdasarkan pengamatan dan observasi peneliti bahwa persoalan pertanahan bahwa harapan tak bersesuaian dengan kondisi pada pelayanan administrasi pertanahan di Kecamatan Jekan Raya. Keadaan yang terjadi di lapangan menunjukkan bahwa beberapa masyarakat yang melakukan pelayanan administrasi pertanahan mengeluhkan proses yang cenderung membutuhkan waktu pelayanan yang lama, termasuk keluhan mengenai kurang ramahnya yang ditunjukkan oleh pegawai kantor kecamatan di kecamatan Jekan Raya, khusunya yang mengurusi masalah pelayanan administrasi pertanahan.

Permasalahan tersebut dikarenakan kasus sengketa tanah yang tumpang tindih karena surat-menyurat yang sama, tetapi lokasi berbeda dan tanah masyarakat itu ada tetapi tidak dikeluarkan oleh pihak kecamatan. Tetapi ada surat yang di klaim masyarakat mana yang banyak kasus premanisme. Permasalahan dilakukan pihak kecamatan dengan jalur mediasi sengketa tanah yang dilaksanakan di Kecamatan Jekan Raya. 
Dilakukannya mediasi tersebut untuk mencari solusi atas permasalahan tanah yang tumpang tindih, tidak mencari yang benar dan yang salah, tetapi mencari solusi bagaimana agar kedua belah pihak yang bersengketa mencari solusi secara kekeluargaan. Pemerintah Kecamatan Jekan Raya hanya sebagai penengah melakukan mediasi terjadinya sengketa tanah antara kedua belah pihak yang bersengketa, mencari solusi yang baik, agar tidak ada pihak yang dirugikan. Masyarakat juga mengeluh karena pelayanan yang ada di pertanahan itu kadang berbelit-belit karena harus melengkapi berkas persyaratan, dan keluar terbitan butuh waktu lama. Proses penerbitan tersebut telah sesuai standar operasional prosedur, namun proses pelayanan pertanahan tersebut ketika mengurus atas kepemilikan tanah masyarakat memerlukan waktu yang masih bisa.

Pelayanan pada dasarnya dapat didefinisikan sebagai aktifitas seseorang, sekelompok dan organisasi baik langsung maupun tidak langsung untuk memenuhi kebutuhannya. Pelayanan yang diperlukan manusia pada dasarnya ada dua jenis yaitu layanan fisik yang sifatnya pribadi sebagai manusia dan layanan administrasi yang diberikan oleh orang lain selaku organisasi, baik itu organisasi massa atau Negara. Dari menurut beberapa pendapat ahli diatas, adapun indikator pelayanan publik mengemukakan lima indikator pelayanan publik, yaitu:

I. Reliability, ditandai pelayanan yang tepat dan benar.

2. Tangibles, ditandai penyediaan yang memadai sumber daya lainnya

3. Responsivines, ditandai keinginan melayani konsumen dengan cepat

4. Assurance, ditandai tingkat perhatian terhadap etika dan moral dalam memberikan pelayanan.

5. Emphaty, ditandai tingkat kemauan untuk mengetahui keinginan dan kebutuhan konsumen.

\section{METODOLOGI}

Penelitian ini ingin mengetahui keseluruhan tentang Kualitas Pelayanan Administrasi Pada Registrasi
Pertanahan maka dalam penelitian ini pendekatan yang dilakukan adalah melalui pendekatan kualitatif. Artinya data yang di kumpulkan bukan berupa angka-angka melainkan data tersebut berasal dari naskah wawancara, catatan lapangan, dokumen pribadi, catatan nemo dan dokumen resmi lainnya. Sehingga yang menjadi tujuan dari peneliti kualitatif ini adalah ingin menggambarkan realita empirik di balik fenomena secara mendalam, rinci dan tuntas.

\section{HASIL DAN PEMBAHASAN}

\section{Tangibles}

Pelayanan pertanahan di Kecamatan Jekan Raya pada hari senin sampai jumat dimulai dari jam 08.00 WIB sampai jam II.30 WIB, jam I2 pelayanan istirahat, lalu disambung lagi jam I3.00 WIB sampai jam I5.00 WIB namun yang peneliti amati di kecamatan baru ada pegawai datang antara jam 08.30 WIB dan jam 09.00 WIB, sehingga yang terlihat jam kerja pelayanan kecamatan seringkali tidak buka sesuai dengan jam yang telah ditentukan sesuai dengan standar operasional prosedur, dan petugas juga datang ke kantor tidak langsung berada di dalam ruangan, petugas ke kantin, petugas juga pulang saat sore hari lebih cepat dari standar pelayanan yang sudah ditentukan, seringkali ruangannya juga kosong tidak ada petugas pelayanan. Pada bidang seksi pemerintahan untuk sarana dan prasarana cukup memadai untuk proses pelayanan, namun peneliti masih melihat tidak ada sarana fisik seperti kipas angin pada ruang tunggu pelayanan, jadi masyarakat merasa panas saat menunggu antrian pelayanan.

\section{Reliability}

Berdasarkan penelitian dan pengamatan di lapangan bahwa pelayanan administrasi pada registrasi pertanahan yang diberikan oleh petugas sudah dilakukan dengan cukup baik, sesuai dengan standar operasional prosedur. Untuk pelayanan di registrasi 
pertanahan ini memiliki dua tempat pelayanan, yaitu didalam ruangan dan dilapangan. Namun peneliti melihat dilapangan bahwa kehandalan yang dimiliki petugas tidak semua sama, ada yang cepat tanggap dan ada juga yang masih lambat dalam memberikan pelayanan.

\section{Responsiviness}

Berdasarkan penelitian dan pengamatan di lapangan bahwa pelayanan administrasi pada registrasi pertanahan yang diberikan oleh petugas sudah dilakukan dengan cukup baik, sesuai dengan standar operasional prosedur. Untuk pelayanan di registrasi pertanahan ini memiliki dua tempat pelayanan, yaitu didalam ruangan dan dilapangan. Namun peneliti melihat dilapangan bahwa kehandalan yang dimiliki petugas tidak semua sama, ada yang cepat tanggap dan ada juga yang masih lambat dalam memberikan pelayanan.

\section{Assurance}

Dalam proses pelayanan kemampuan dan keramahan serta sopan santun pegawai dalam meyakinkan kepercayaan konsumen sangatlah penting demi menunjang proses pelayanan pada bidang seksi pemerintahan. Berdasarkan penelitian dan pengamatan bahwa pelayanan administrasi pada registrasi pertanahan yang diberikan oleh petugas sudah dilakukan dengan baik, sesuai dengan standar operasional prosedur, namun kadang peneliti melihat masih ada petugas yang memberikan pelayanan dengan wajah yang cuek,raut wajah yang cemberut, serta dalam proses pelayanan tidak terlihat senyum,sapa.

5. Emphaty

Dari hasil wawancara dengan masyarakat dapat diketahui masalah kesediaan petugas dalam melayani masyarakat sudah baik dengan banyaknya tanggapan masyarakat yang menyatakan cukup baik. Pemberian Pelayanan kesediaan aparat dalam memberikan informasi merupakan hal yang perlu mendapat perhatian. Kesediaan pegawai dalam memberikan informasi terhadap masyarakat yang membutuhkan pelayanan akan dapat memperbaiki cara pelayanan di mata masyarakat. Sehingga dalam menciptakan pelayanan prima masyarakat perlu didukung dengan adanya pegawai yang berempati dalam membantu kebutuhan masyarakat yang butuh informasi.

\section{KESIMPULAN}

Dari lima indikator diatas peneliti lebih memfokuskan permasalahan reliability yang dimana keandalan pegawai dalam memberikan pelayanan yang tepat dan benar. Karena permasalahan yang terjadi dilapangan bahwa keandalan petugas masih kurang dalam memberikan pelayanan, masih banyaknya berkas-berkas dokumen masyarakat di atas meja pegawai, pelayanan petugas dalam keandalan secara benar dan tepat dalam mengurus surat tanah masih belum maksimal. Masih terdapat petugas yang belum mahir dalam mengoperasikan komputer, hanya bisa secara otodidak. Dalam memberikan pelayanan yang baik untuk masyarakat pihak Kecamatan Jekan Raya dalam proses pelayanan perlu ditingkatkan lagi, terutama sarana dan prasarana perkantoran seperti penambahan kipas angin diruang tunggu, kursi tunggu ditambah lagi, tersedianya bacaan seperti majalah, koran diruang tunggu, agar masyarakat yang melakukan proses pelayanan merasa nyaman terhadap pelayanan yang diberikan. Agar berjalannya proses pelayanan di Kecamatan Jekan Raya dengan baik, petugas pelayanan agar tepat waktu dalam memberikan pelayanan, karena yang sering terjadi ada masyarakat yang ingin melakukan pelayanan, tetapi tidak ada petugas di dalam ruangan. Agar kesadaran Sumber Daya Manusia petugas untuk lebih ditingkatkan lagi serta perlu adanya komitmen untuk bisa memberikan pelayanan yang lebih baik untuk masyarakat demi terwujudnya pelayanan yang prima. Sesuai dengan Standar operasional prosedur bahwa petugas pelayanan 
memberikan pelayanan dengan ramah, sapa dan senyum. Karena masyarakat masih ada yang mengeluh pada saat proses pelayanan bahwa petugas pelaanan memberikan pelayanan dengan wajah cuek. Pada akhirnya, agar keandalan pegawai dalam menyelesaikan berkas permohonan masuk masyarakat lebih di tingkatkan kembali.

\section{REFERENSI}

Anggara, S. 2012. Ilmu Administrasi Negara. Bandung: Pustaka Setia.

Dwiyanto, A. 2014. Mewujudkan Good Governance mellaui pelayanan publik. Yogyakarta: Gadjah Mada University Press.

Hardiyansyah. 20II. Kualitas Pelayanan Publik Konsep, Dimensi, Indikator, dan Implementasinya. Yogyakarta: Gaya Media.

Moelong, J.L. 2012. Metode Penelitian Kualitatif. Bandung: Remaja Rosdakarya.

Mukarom, Z. 20I5. Manajemen Pelayanan Publik. Bandung: Pustaka Setia.

Pasolong, H. 20I3. Teori Administrasi Publik. Jakarta: Alfabeta.

Ridwan, J. 2009. Hukum Administrasi Negara dan Kebijkaan Pelayanan Publik. Jakarta: Nuansa.

Sedarmayanti. 2009. Reformasi Administrasi Publik, Reformasi Birokrasi, dan Kepemimpinan Masa Depan (Mewujudkan pelayanan prima dan kepemerintahan yang baik). Bandung: Refika Aditama.

Sinambela, P.L. 2010. Reformasi Pelayanan Publik Studi, Kebijakan, dan Implementasi. Jakarta: Bumi Aksara.

Syafri, W. 2012. Studi Tentang Administrasi Publik. Jakarta: Erlangga. 